\title{
LA-UR-18-23773
}

Approved for public release; distribution is unlimited.

Title: $\quad$ Special Analysis: 2016-002, Analysis of Cover Erosion and Enhanced Infiltration at Pit 25, TA-54 Area G

Author(s): $\quad$ Birdsell, Kay Hanson

Dai, Zhenxue

Stauffer, Philip H.

French, Sean B.

Intended for: $\quad$ Report

Issued: $\quad$ 2019-02-08 (rev.1) 
Disclaimer:

Los Alamos National Laboratory, an affirmative action/equal opportunity employer, is operated by Triad National Security, LLC for the National Nuclear Security Administration of U.S. Department of Energy under contract 89233218CNA000001. By approving this article, the publisher recognizes that the U.S. Government retains nonexclusive, royalty-free license to publish or reproduce the published form of this contribution, or to allow others to do so, for U.S. Government purposes. Los Alamos National Laboratory requests that the publisher identify this article as work performed under the auspices of the U.S. Department of Energy. Los Alamos National Laboratory strongly supports academic freedom and a researcher's right to publish; as an institution, however, the Laboratory does not endorse the viewpoint of a publication or guarantee its technical correctness. 


\section{Special Analysis: 2016-002 Analysis of Cover Erosion and Enhanced Infiltration at Pit 25, TA-54 Area G}

UDQE Reference Number:

UDQE-1602

Authors:

Kay Birdsell, Zhenxue Dai, Philip H Stauffer, and Sean B. French Los Alamos National Laboratory

Prepared for:

Los Alamos National Laboratory

Date:

February 2019 
Special Analysis: Pit 25 Erosion and Enhanced Infiltration 


\section{Table of Contents}

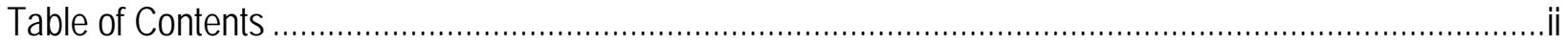
List of Tables .............................................................................................Error! Bookmark not defined. No table of contents entries found. .............................................................Error! Bookmark not defined. Acronyms and Abbreviations .......................................................................................................

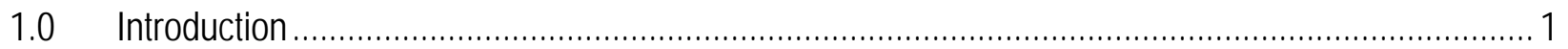

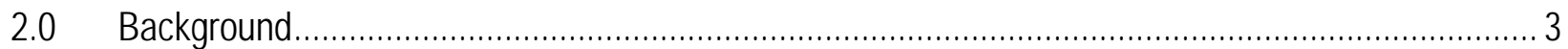

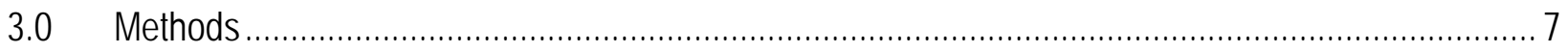

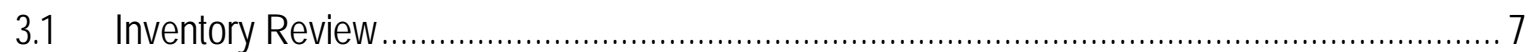

3.2 Photo Documentation of Pit 25 Interim Cover................................................................. 8

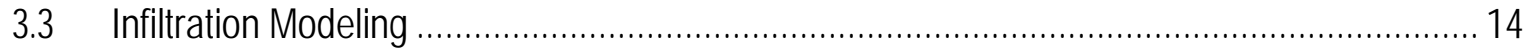

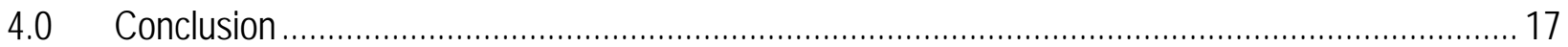

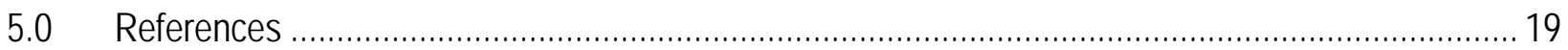

\section{Acronyms and Abbreviations}

$\begin{array}{ll}\text { CA } & \text { Composite Analysis } \\ \text { D\&D } & \text { Decontamination and Decommissioning } \\ \text { DOE } & \text { Department of Energy } \\ \text { LANL } & \text { Los Alamos National Laboratory } \\ \text { LLW } & \text { Low-level radioactive waste } \\ \text { PA } & \text { Performance Assessment } \\ \text { SA } & \text { Special Analysis } \\ \text { TA-54 } & \text { Technical Area 54 } \\ \text { UDQ } & \text { Unreviewed Disposal Question } \\ \text { UDQE } & \text { Unreviewed Disposal Question Evaluation }\end{array}$




\subsection{Introduction}

The Los Alamos National Laboratory (LANL) generates radioactive waste as a result of various activities. Operational waste is generated from a wide variety of research and development activities including nuclear weapons development, energy production, and medical research. Environmental restoration, and decontamination and decommissioning (D\&D) waste is generated as contaminated sites and facilities at LANL undergo cleanup or remediation. The majority of this waste is low-level radioactive waste (LLW) and is disposed of at the Technical Area 54 (TA-54), Area G disposal facility.

U.S. Department of Energy (DOE) Order 435.1 (DOE, 2001) requires that radioactive waste be managed in a manner that protects public health and safety, and the environment. To comply with this order, DOE field sites must prepare site-specific radiological performance assessments for LLW disposal facilities that accept waste after September 26, 1988. Furthermore, sites are required to conduct composite analyses that account for the cumulative impacts of all waste that has been (or will be) disposed of at the facilities and other sources of radioactive material that may interact with the facilities.

Revision 4 of the Area $G$ performance assessment and composite analysis (PA/CA) was issued in 2008 (LANL, 2008). The analyses in that document estimate radionuclide release rates from the waste disposed of at the facility, simulate the movement of radionuclides through the environment, and project potential radiation doses to humans for several onsite and offsite exposure scenarios. The assessments were based on existing site and disposal facility data, and assumptions about future rates and methods of waste disposal. Several model updates have been conducted since the Revision 4 results were published in 2008 (LANL, 2008), including inventory updates to reflect annual disposal receipt reviews as published in the site annual reports, and in special analyses (SAs) that were performed in response to unreviewed disposal question evaluations (UDQE); the most recent examples are SA 2016-001 (Chu et al., 2017a) and SA 2016-003 (Chu et al., 2017b).

Site performance and the predictions made by the PA/CA models are based on assumptions regarding cover performance, erosion rates, and infiltration rates. If cover performance is inadequate, assumptions may be invalid and the site may not perform as well as predicted by the PA/CA models. Unreviewed Disposal Question Evaluation (UDQE) 1602 (Appendix A) identified a positive unreviewed disposal question (UDQ) related to the interim cover on Pit 25 at Area G. The UDQE identified that enhanced erosion had occurred on the Pit 25 interim cover, and also that a portion of Pit 25 has an unconventional cover. Unconventional cover test plots designed to test various bio-intrusion barriers were constructed in the early 1980s (Nyhan et al., 1986; Nyhan 1989). The construction of the test plots differs from the conventional crushed-tuff operational covers used for most pits at Area G. As part of the Nyhan et al. (1986; 1989) studies of the test 
plots, enhanced infiltration into the underlying waste in Pit 25 was observed. This special analysis (SA) 2016-002 documents the potential impact of the presence of and erosion of these uncoventional test covers. It also looks at the potential impact of increased infiltration into the pit because of the test covers. The SA recommends actions to repair and enhance the interim cover on Pit 25. 


\subsection{Background}

Notable erosion was observed in the operational cover at Pit 25 at Area G in March 2105 during a site walkdown following clean-up of excess material (e.g., rows of large metal containers, and piles of pallets and scrap metal) at a surface disposal site known as the "boneyard." The field team observed evidence of run-on, erosion, and ponding over Pit 25 and part of Pit 26. In addition, they noticed possible vertical metal panels of unknown origin within the Pit 25 cover. Figures 2-1 and 2-2 show two photographs documenting the field observations on March 5, 2015.

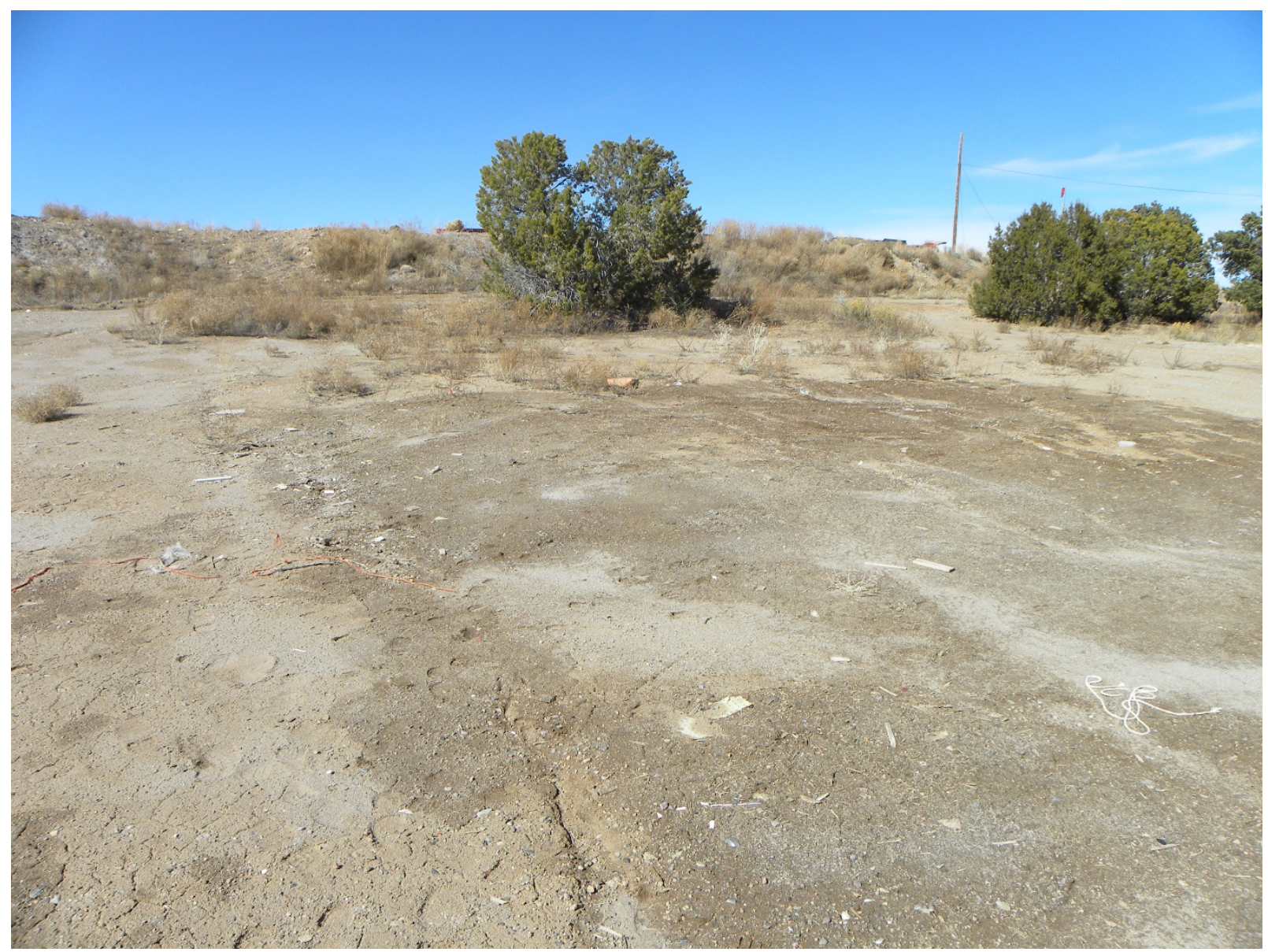

Figure 2-1. Photograph showing signs of erosion and wet surface conditions at Pit 25, March 5, 2015. 


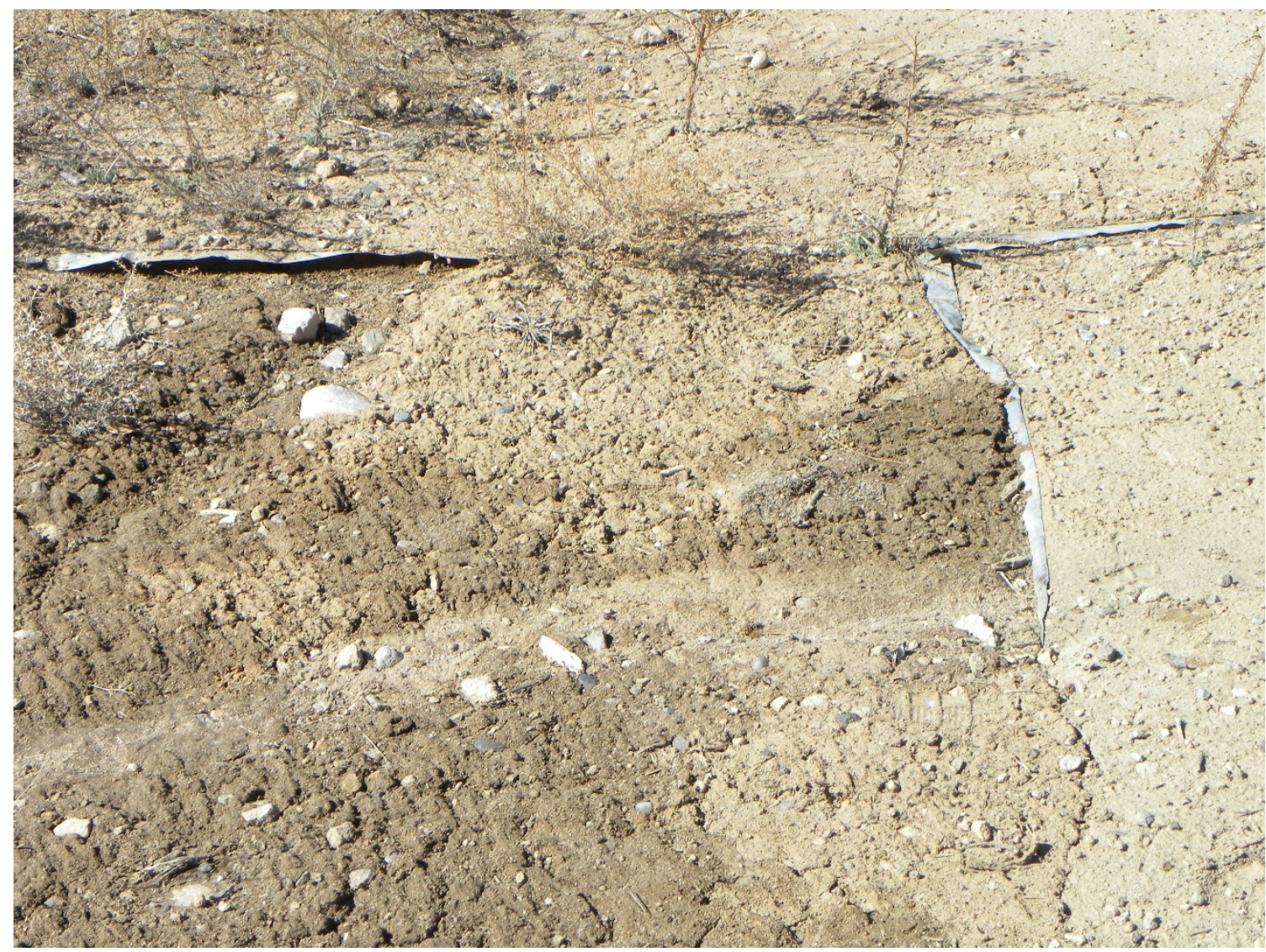

Figure 2-2. Photograph showing possible vertical metal panels in Pit 25 operational cover, and signs of erosion and wet surface conditions, March 5, 2015.

Pit 25 has an operational cover. It was determined that the linear metal strips observed in the Pit 25 cover (Figure 2-2) are most likely associated with four unconventional bio-intrusion-barrier test plots that were constructed over a portion of the pit (Nyhan et al., 1986; Nyhan, 1989) when Pit 25 was closed in late 1981. The test plots were placed on top of the waste and backfill to monitor the performance of pit cap designs with respect to plant root intrusion and uptake, and percolation of water into the pit backfill (Figure 2-3). Each of the four plots has a size of $6 \mathrm{~m} \mathrm{x} 12 \mathrm{~m}$ and a thickness of $1 \mathrm{~m}$. They are covered with $15 \mathrm{~cm}$ of topsoil. Plot 1 to Plot 4 consists of $15 \mathrm{~cm}$ gravel and $85 \mathrm{~cm}$ of cobble; $100 \mathrm{~cm}$ of cobble; $100 \mathrm{~cm}$ of crushed tuff; and $30 \mathrm{~cm}$ gravel and $70 \mathrm{~cm}$ cobble, respectively (Figure 2-4). The test plots cover $8.0 \%$ of Pit 25, based on its size [120 m x 3 m, (Table 1 of French and Shuman, 2014)]. 


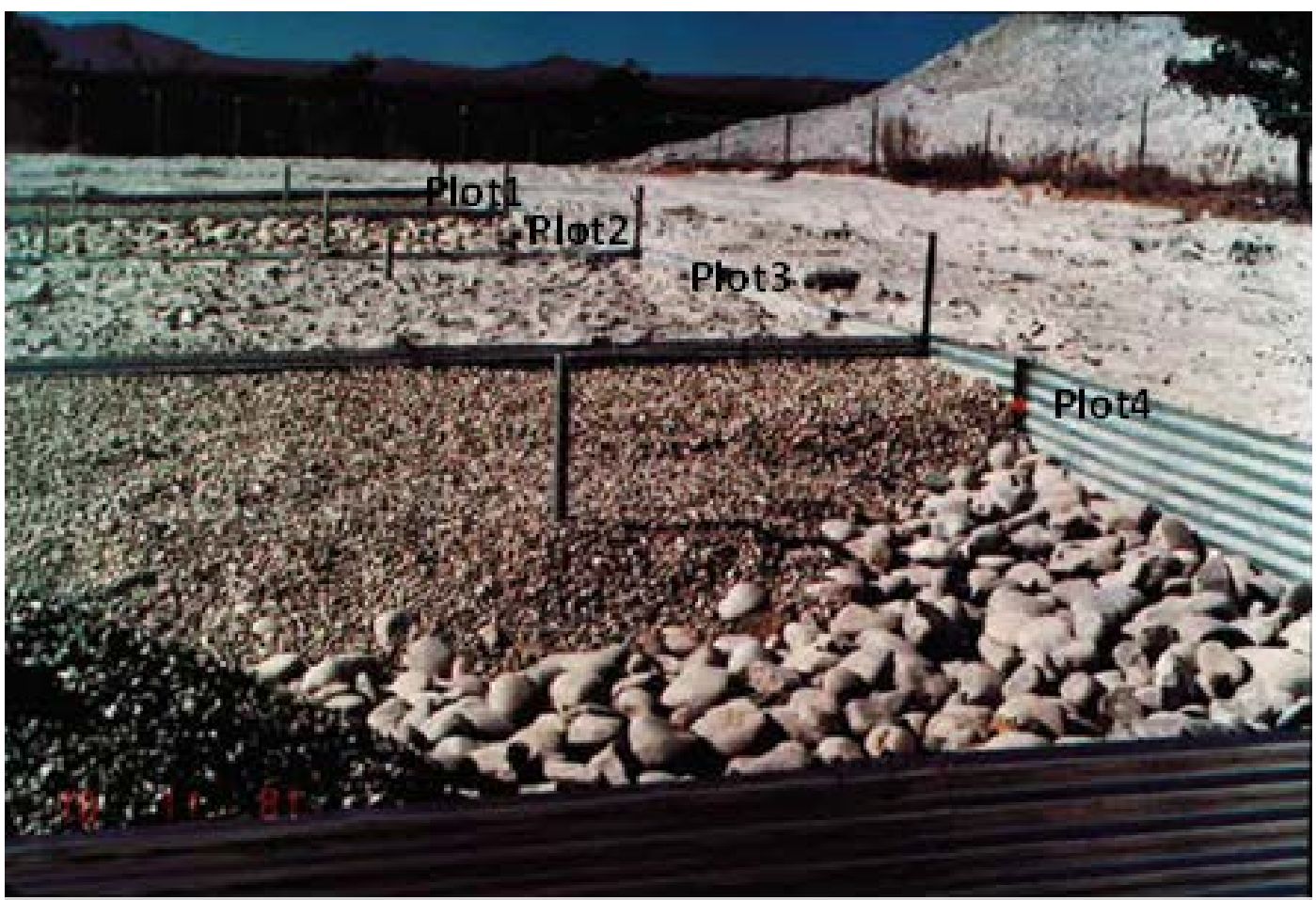

Figure 2-3: Four bio-intrusion-barrier plots constructed on part of Pit 25 in 1981. Portions of the barrier materials are shown here during construction, before the final $15 \mathrm{~cm}$ of topsoil was added on each plot.

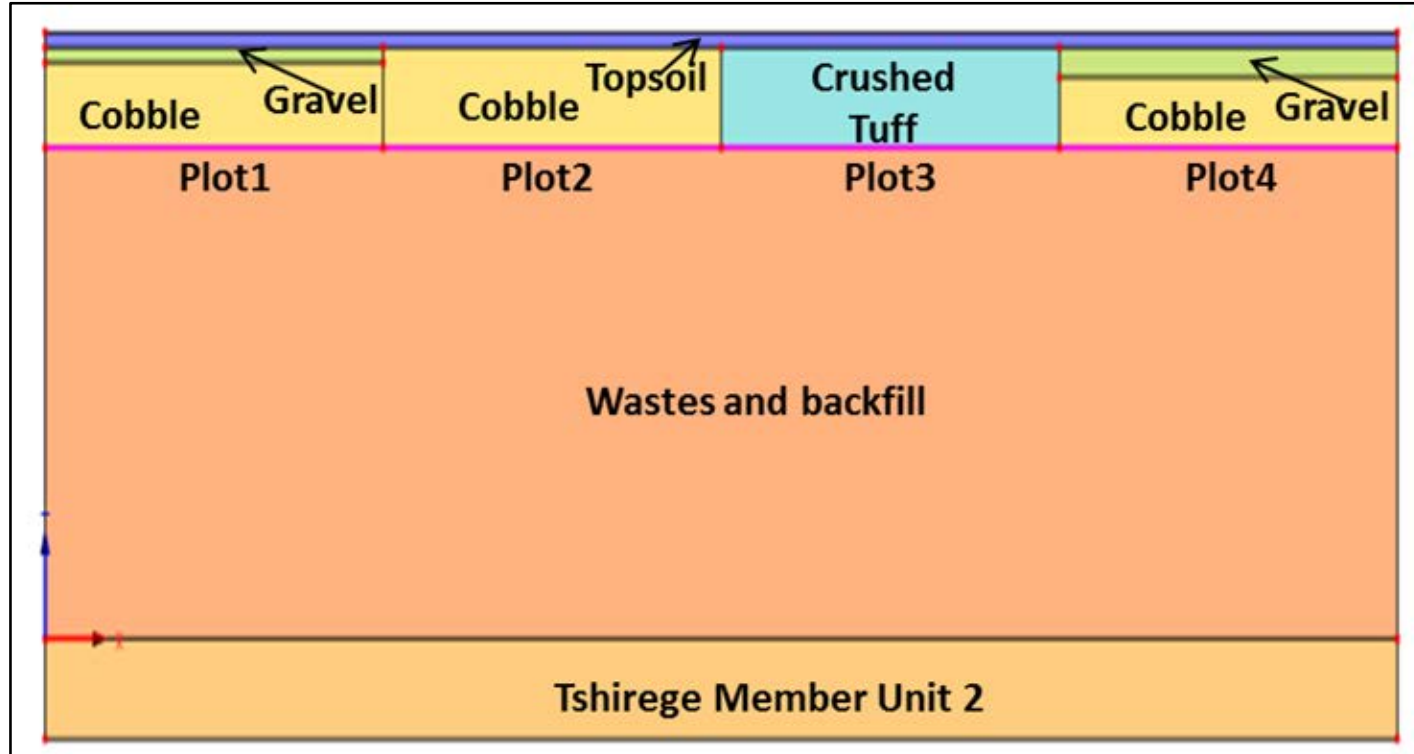

Figure 2-4: A two-dimensional framework model for Pit 25 with topsoil, four different biointrusion-barriers, waste and backfill, and Tshirege Member unit 2. 
Neutron moisture access tubes were installed to a depth of $137 \mathrm{~cm}$ (or $30 \mathrm{~cm}$ into the backfill) through each of the four plots and into the underlying backfill to allow for time-series monitoring of moisture in the backfill (Nyhan et al. 1986; Nyhan et al. 1989). The monitoring started in January 1, 1982 and ended in August 13, 1985. In addition, soil water content was monitored in each of the four plots, at different depths (spatial-series) from $10 \mathrm{~cm}$ to $137 \mathrm{~cm}$ for a single event at the end of April, 1985.

During their study, Nyhan et al. (1986; 1989) observed that the bio-barrier cover designs inhibited plant root intrusion into the underlying backfill and waste. However, enhanced infiltration beneath the covers and into the underlying waste layer was observed. That portion of the cover was never replaced with a conventional crushed tuff cover. In 2015, the cover showed significant signs of erosion. These conditions of both enhanced erosion and enhanced infiltration differ from those assumed in the Area G Performance Assessment and Composite Analysis. Therefore, this SA presents additional work conducted to determine the possible impacts of these conditions, and makes recommendations for corrective actions. 


\subsection{Methods}

Special Analysis 2016-002 documents the potential impact of the presence of and erosion of the unconventional test covers located in the Pit 25 cover, as well as erosion across the area. For this task, a review of the radionuclide inventory is included. Then repeat photo documentation is used to assess erosion in the Pit 25 operational cover between March 2015 and March 2018. This SA also determines the potential impact of increased infiltration into Pit 25 because of the test covers. Hydrologic modeling was used to simulate infiltration through the test covers from approximately their installation in 1981 into early 2016. The modeling uses the software package Hydrus 2D, and infiltration is based on local meteorological conditions. Details are provided in Appendix B.

\subsection{Inventory Review}

According to summary information provided in Appendix J (Table 1) of Revision 4 of the Area $G$ PA/CA (LANL, 2008), Pit 25 was operational from December, 1979 through June, 1981. It received reactor control rods, D\&D waste, scrap drums, lab wastes, test drums, and PCBcontaminated waste. Approximately 4,600 m3 of LLW was disposed in Pit 25, which has approximate dimensions of $120 \mathrm{~m}$ x $30 \mathrm{~m}$ x $13 \mathrm{~m}$. The estimated total activity of LLW disposed in Pit 25 is $370 \mathrm{Ci}$. Table 1 provides the radionuclide inventory for Pit 25 obtained from the PA/CA inventory model. The radionuclides Co-60, Cs-137, and H-3 make up 99\% of the inventory in the pit; these nuclides are all relatively short-lived with half-lives of 5.3, 30, and 12.3 years, respectively.

Table 1. Radionuclide Inventory for Pit 25

\begin{tabular}{|c|c|c|}
\hline $\begin{array}{l}\text { Radionuclide or } \\
\text { Material Type }\end{array}$ & $\begin{array}{l}\text { Waste Inventory } \\
\text { (Ci) }\end{array}$ & $\begin{array}{l}\% \text { of total } \\
\text { inventory }\end{array}$ \\
\hline Am-241 & $3.22 \mathrm{E}-03$ & $8.6 \mathrm{E}-04$ \\
\hline Co-60 & $1.21 \mathrm{E}+02$ & 32.3 \\
\hline Cs-137 & $2.00 \mathrm{E}+02$ & 53.4 \\
\hline H-3 & $5.01 \mathrm{E}+01$ & 13.4 \\
\hline Pu-238 & 1.17E-03 & 3.1E-04 \\
\hline Pu-239 & $5.40 \mathrm{E}-02$ & $1.4 \mathrm{E}-02$ \\
\hline Pu-240 & $5.02 \mathrm{E}-07$ & $1.3 \mathrm{E}-07$ \\
\hline Sr-90 & 1.09E-02 & $2.9 \mathrm{E}-03$ \\
\hline U-235 & $9.97 \mathrm{E}-03$ & $2.7 \mathrm{E}-03$ \\
\hline U-238 & $1.22 \mathrm{E}+00$ & 0.3 \\
\hline MAP & 1.01 & 0.3 \\
\hline MFP & 1.2 & 0.3 \\
\hline PU52 & 1.98E-02 & 5.3E-03 \\
\hline PU83 & $3.74 \mathrm{E}-04$ & $1.0 \mathrm{E}-04$ \\
\hline U12 & $1.37 \mathrm{E}-01$ & $3.7 \mathrm{E}-02$ \\
\hline
\end{tabular}




\subsection{Photo Documentation of Pit 25 Interim Cover}

Site visits to Pit 25 were conducted in September 2015, November 2017, and April 2018 to determine whether erosion of the cover material had occurred since the original problem was noted in March 2015. Photographic documentation was used to monitor the progress. Here, we compare photographs from March 2015 to those taken in either November 2017 or April 2018. The latter two sets are used to compare to the March 2015 photos because they document the longer-term change over the study period. In addition, effort was made during the two site visits to capture similar view angles to those used in March 2015. We revisited the site in April 2018 to capture photos during the same season as the original photos so that vegetation was most similar to ensure that our comparisons were not being influenced by the presence of vegetation. We note that March 2015 was much wetter than April 2018, so the wetness of the soil is probably more a function of the previous weather conditions than cover performance.

Figures 3-1 through 3-5 show the photographic comparisons between conditions in March 2015 to those from November 2017 or April 2018. The March 2015 photographs were taken relatively soon after site cleanup (Section 2) was conducted when little vegetation was present. Observations noted from this comparison of photos show the following changes in the roughly 2.5 to 3 years since the original photographs were taken.

- Vegetation has moved into the area. We note that there is more vegetation at the edge of the test plots than within the test plots. This indicates that the bio-barrier test plots are limiting plant growth to an extent.

- Rather than additional erosion, soil deposition has occurred; many fewer rills and cracks in the soil are noted, and the metal strips have become harder to locate.

- Cobbles from the test plots are visible at the surface. Because both the cobbles and metal strips are present at the surface, this indicates that is no additional fill or cover has been placed over the test plots that were installed in 1981.

Flags were placed during the April 2018 site visit to help determine the extents of the four test plots based on the original dimensions noted in the Nyhan et al. reports (1986; 1989) and the ability to locate some of the metal strips that outline the test plots (Figure 3-6). The team is convinced that the metal strips demarcate the test plots. 


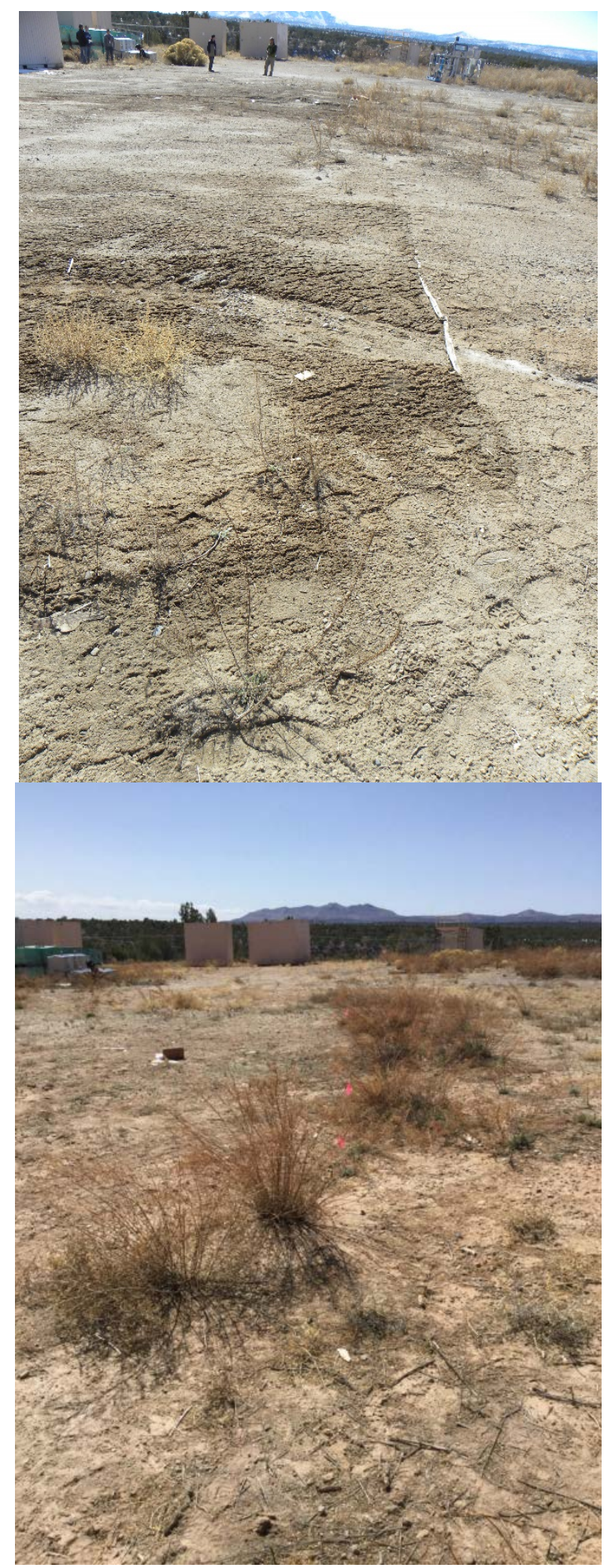

Figure 3-1. Pit 25 looking west, (top) photo from March 5, 2015, showing erosion rills and east-west running metal strip at northern edge of test plots; (bottom) photo from April 3, 2018, showing fewer rills, additional vegetation, and flags marking location of metal strip at northern edge of test plots. 


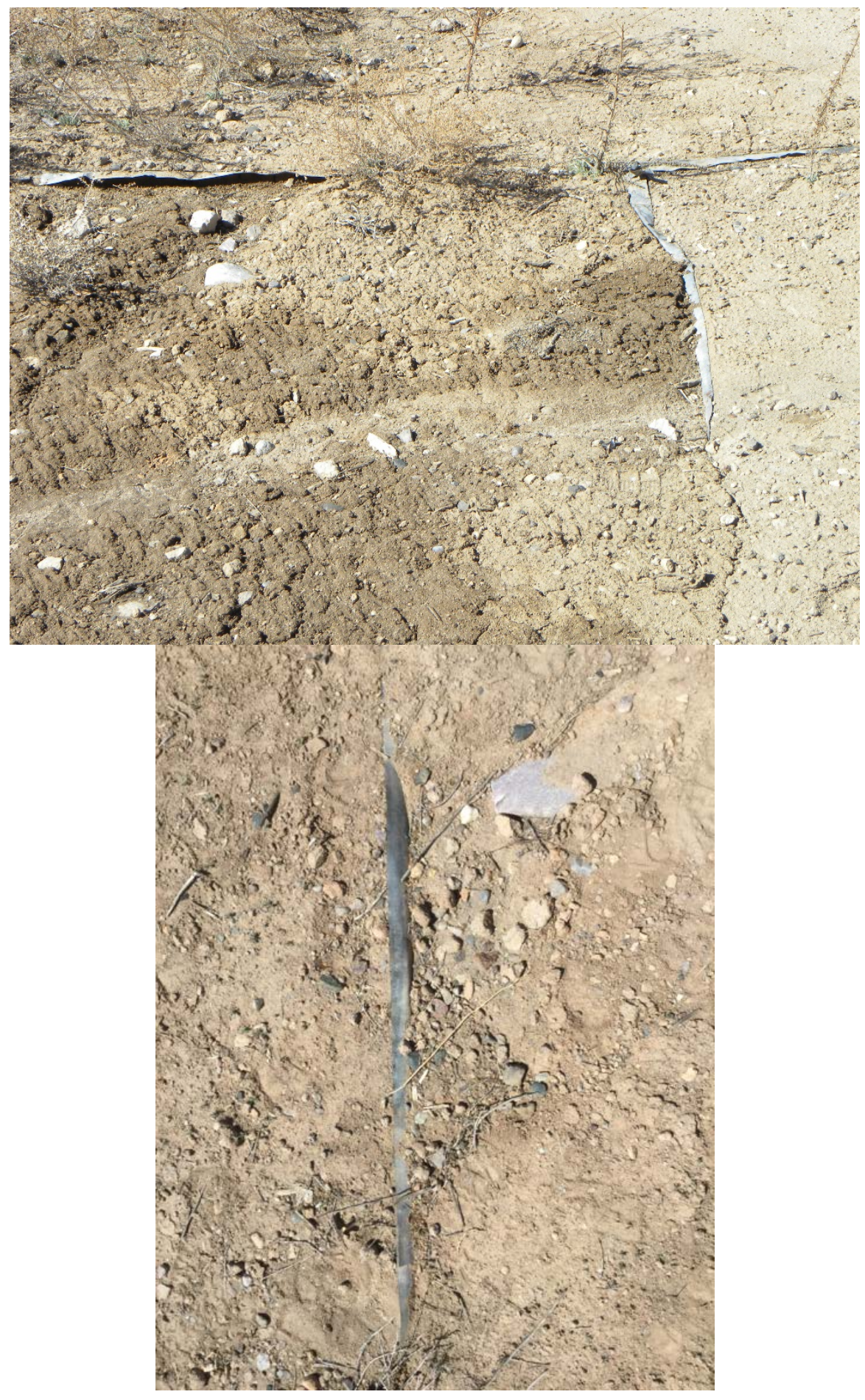

Figure 3-2. Pit 25 looking north, (top) photo from March 5, 2015, showing erosion rills and junction of metal strips that bound the test plots; (bottom) photo from April 3, 2018, showing north-south running metal strip near northern edge of test plots; junction shown in top figure is covered. Both photos show cobbles from the test plots. 


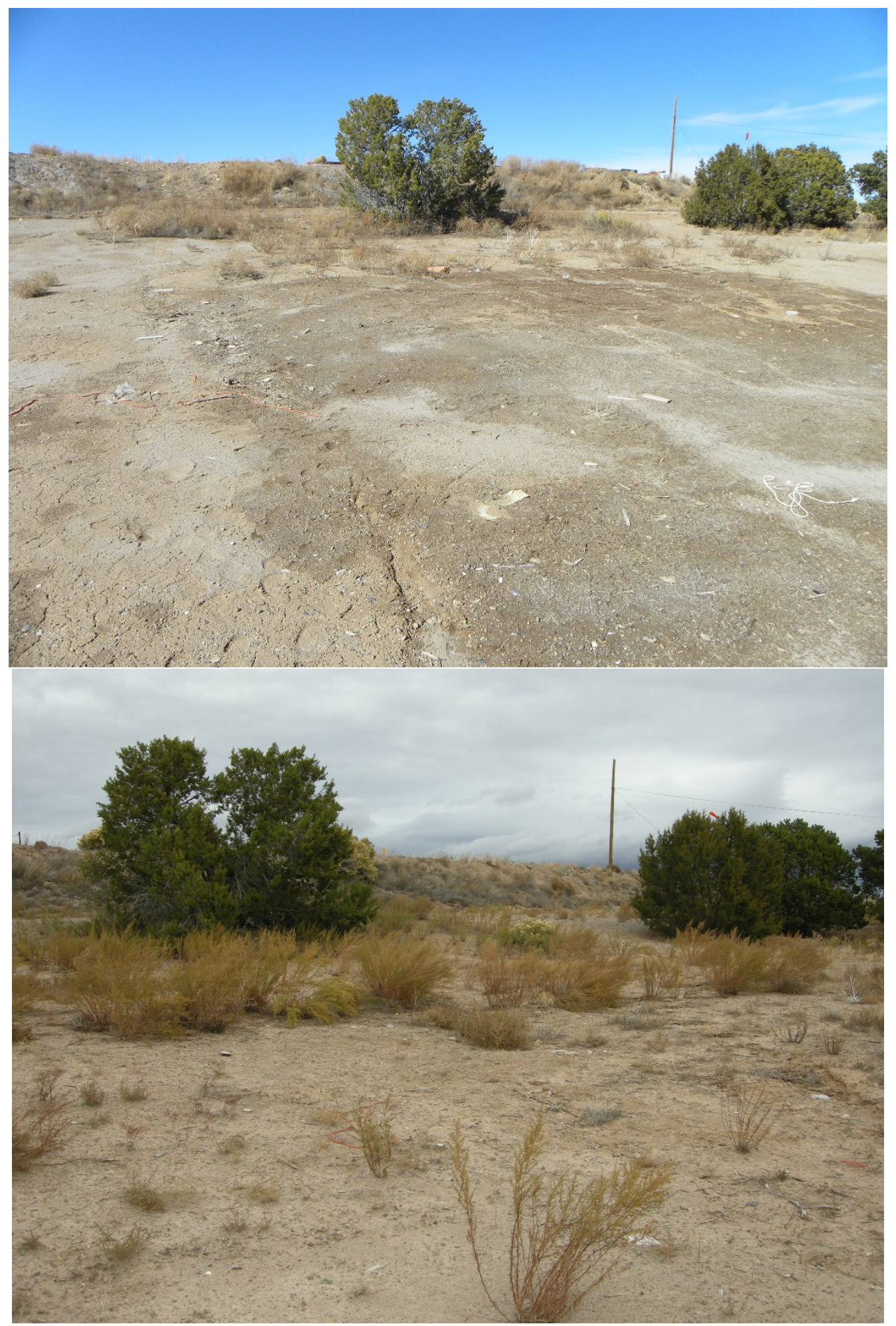

Figure 3-3. Pit 25 looking north-northeast, (top) photo from March 5, 2015, showing erosion rills and wet surface conditions; (bottom) photo from November 7, 2017, showing fewer rills, additional vegetation and soil, and drier conditions. 


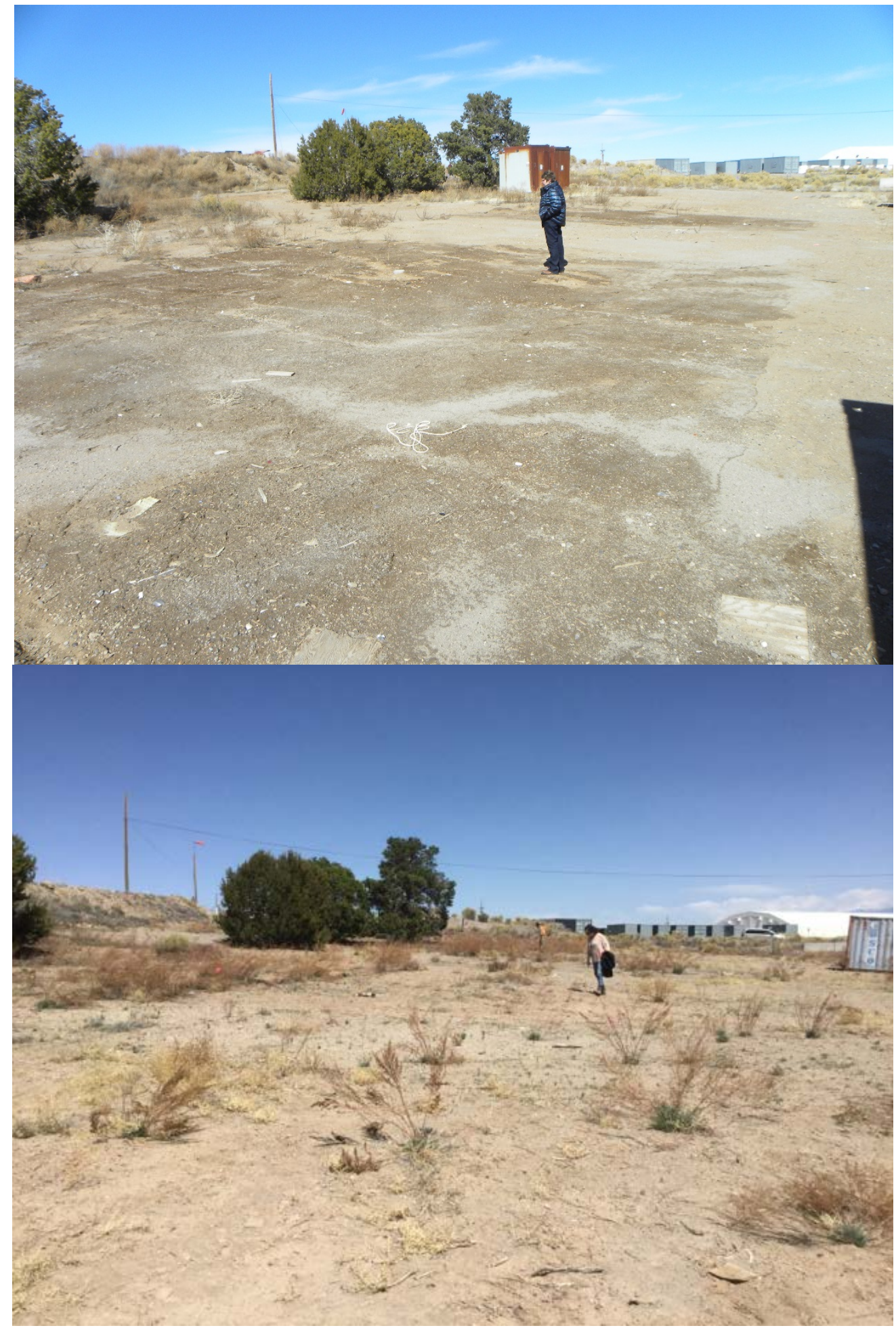

Figure 3-4. Pit 25 looking east-northeast, (top) photo from March 5, 2015, showing erosion rills and wet surface conditions; (bottom) photo from April 3, 2018, showing fewer rills, additional vegetation, and a flag marking the northern edge of the test plots. 

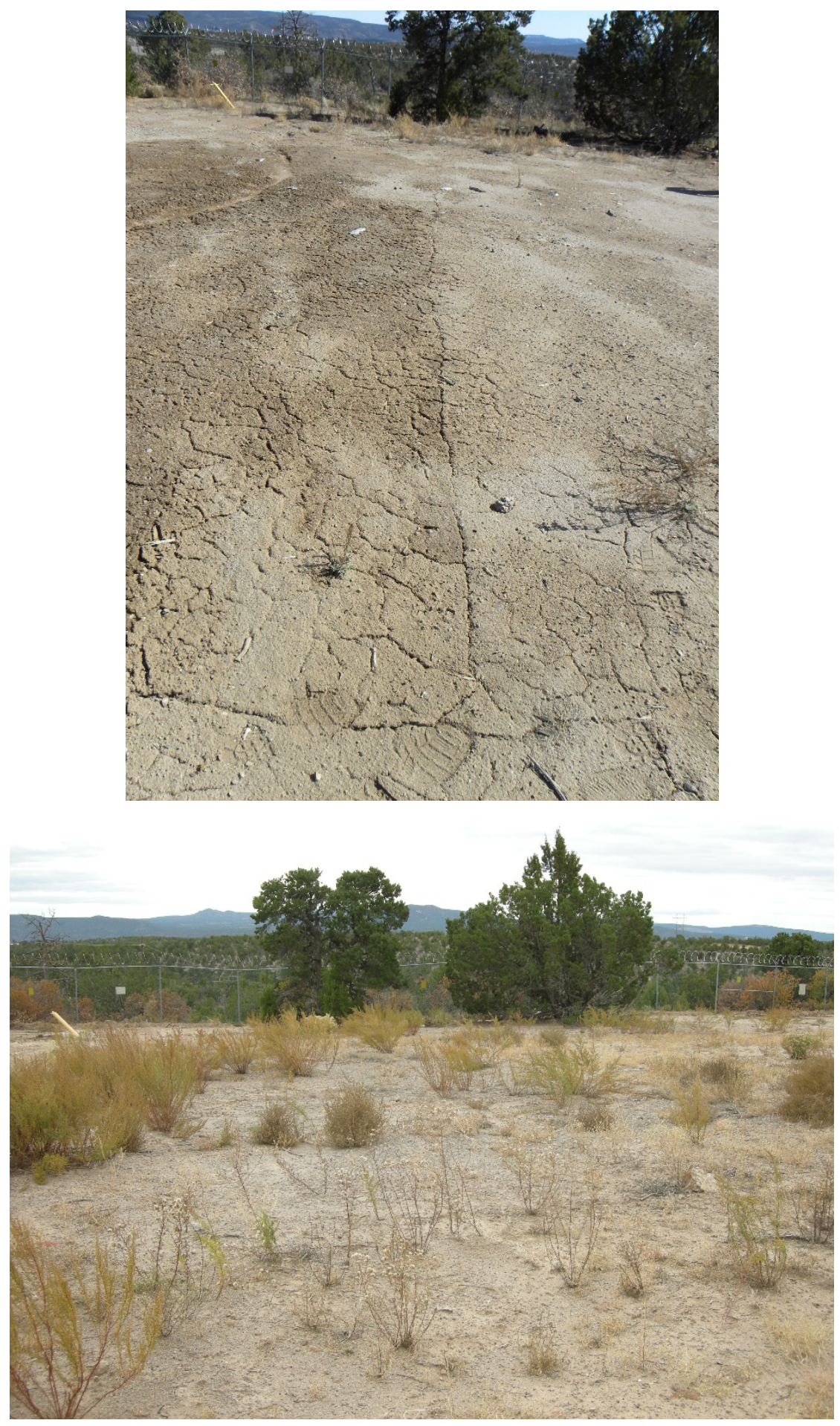

Figure 3-5. Pit 25 looking south, (top) photo from March 5, 2015, showing erosion rills, surface cracking, and wet surface conditions; (bottom) photo from November 7, 2017, showing fewer rills, and additional vegetation and presence of new soil. 


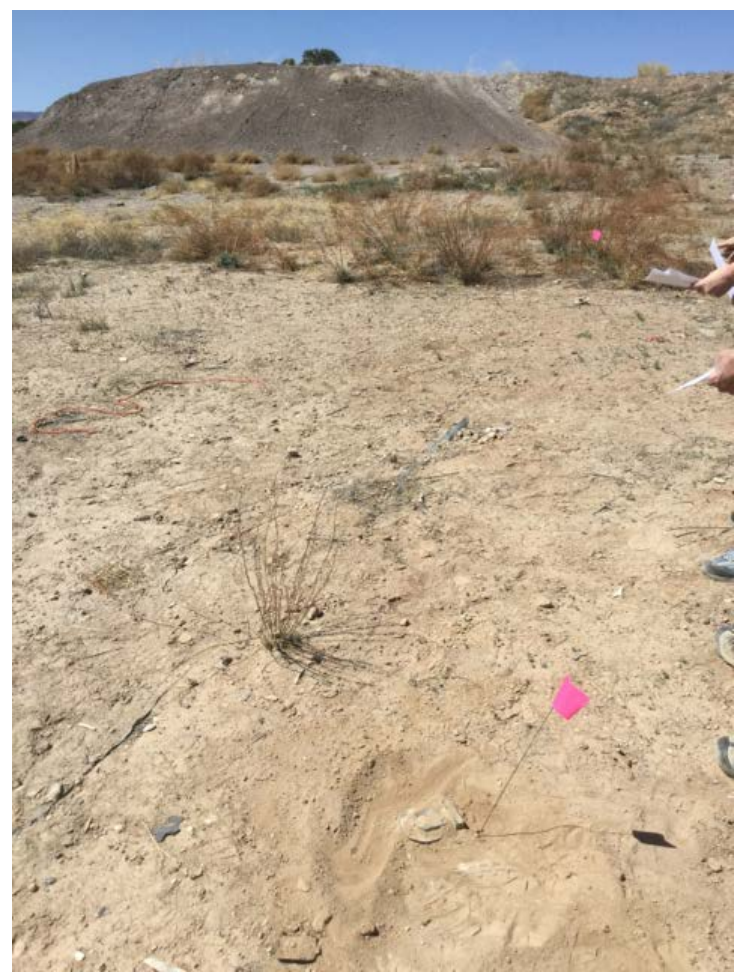

Figure 3-6. Pit 25 looking north, photo from April 3, 2018, showing north-south running metal strip; approximate location of junction with east-west running metal strip is marked with a flag near the top of the photo. The flag in the lower portion of the photo is likely a neutron access hole installed into the test cover.

\subsection{Infiltration Modeling}

A two-dimensional, cross-sectional flow model was built using the HYDRUS2D model (Šimůnek et al., 2011) to simulate water percolation through the four bio-intrusion barriers into the waste and backfill at Pit 25. The model set-up and simulation results are documented in Appendix B. Water percolation rates across the bottom of the four plots were simulated for the time period January 1, 1982 to January 18, 2016, using precipitation data from the TA-54 weather station. Simulated moisture contents were compared to moisture data collected from beneath and within the test covers from 1982 to 1985 (Nyhan et al., 1986; Nyhan, 1989).

The important features of the computed percolation rates at the bottoms of the pits are that the flow rates beneath Plot 2 (100 cm of cobble) are the largest because the cobble has the largest conductivity and the van Genuchten parameters are not condusive to retaining water. The percolation rates through Plot 1 (15 cm gravel and $85 \mathrm{~cm}$ cobble) and Plot 4 (30 gravel and 70 cobble) are also enhanced, with flow rates through Plot 1 larger than through Plot 4 because of the higher ratio of cobble to gravel. The flow rates across the bottom of Plot 3 (100 cm crushed 
tuff) are the lowest because crushed tuff has the smallest hydraulic conductivity and the highest water retention capacity (i.e., ability to damp out transient pulses). Plot 3 is constructed similarly to the conventional operational cover at Area G.

The cumulative flow rates across the base of the four test plots in shown in Figure 3-7.

Cummulative flow across the base of the crushed tuff test plot is much less than those of the other three test plots, which have less water retention capacity. These results indicate that cummulative flows through Plots 1, 2, and 4, which are constructed primarily of coble, are 1.7 to 2.3 times the volume of water that has percolated into the waste through Plot 3 , which is constructed of crushed tuff. Therefore, enhanced infiltration is occurring through three of the four test plots in comparison to a conventional operational cover constructed of crused tuff. This condition of enhanced infiltration is inconsistent with assumptions related to groundwater flow used in the PA/CA.

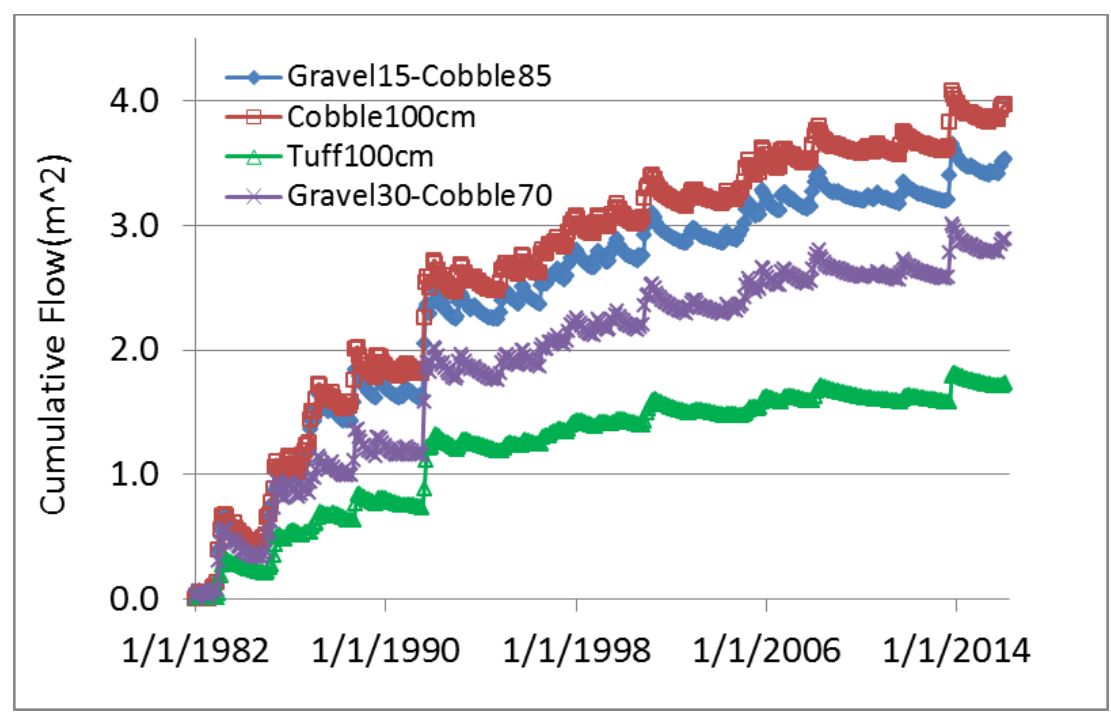

Figure 3-7: Computed cumulative water flow rates $\left(\mathrm{m}^{2}\right)$ across the bottoms of the four test plots

The results of the infiltration analysis through Pit 25 are compared to those for Pit 38 (Dai et al., 2018; Pawar et al., 2018) to provide context on how the enhanced infiltration may impact the groundwater pathway. Infiltration rates through test plot 2 at Pit 25 are the highest calculated with the HYDRUS modeling presented in Appendix B. Comparison with the HYDRUS modeling presented by Dai et al., (2018) for Pit 38 East show similar order of high magitude flow events through the three cobble test plots and Pit 38 East (i.e., order of magnitudes of $0.005-0.01 \mathrm{~m}^{2} /$ day). However the flow rates through the Pit 25 test plots are not as continuous as those calculated for Pit 38 East. The high flows through the test plots directly result from rain events and are of very short duration, whereas those calcualted for Pit 38 East are more continuous. The impact of enhanced infiltration through Pit 38 was used to calculate the groundwater pathway (Pawar et al., 
2018). C-14, which is a mobile species with a significant inventory is Pit 38, was found to have a complete pathway to groundwater, but other radionuclides were screened out (French et al., 2013). The inventory analysis for Pit 25 (Section xx) showed that the short-lived radionuclides Co-60, Cs-137, and H-3 make up 99\% of the inventory in the pit. Because the flow rates for infiltration into Pit 25 is calculated to be lower than that for Pit 38 East, the test plots that have enhanced infiltration cover only $8 \%$ of Pit 25 and would not interact with much of the inventory in the pit, and the main constituents in the inventory are short-lived and would therefore decay before reaching the regional aquifer, the groundwater pathway for Pit 25 has a much lower chance of being complete than for Pit 38. Therefore, although infiltration is enhanced through the test plots, this qualitative assessment indicates that significant transport of radionuclides to groundwater has probably not occurred. 


\subsection{Conclusions and Recommendations}

\subsection{Conclusions}

Special Analysis 2016-002 documents conditions of the interim cover that is currently in place over Pit 25 at Area G. The SA notes evidence of erosion of the interim cover. However, between March 2015 when erosion was originally observed and the last two site visits in November 2017 and April 2018, more vegetation has grown at the site, and soil deposition has filled in some of the erosion rills and repaired some of the soil cracks.

The SA documents the presence of unconventional test covers within a portion of the Pit 25 interim cover. The construction of these test covers, was intended to test bio-barriers. Based on their dimensions, the test plots cover approximately $8 \%$ of the surface area of Pit 25 . The photographic evidence appears to show less vegetation where the covers are present than outside. The evidence also shows that little to no additional cover is currently present over the test plots. Given that the test plots were constructed to be 1-m thick, this indicates the interim cover on Pit 25 currently has an approximately 1-m thick cover, at least in the area of the test plots.

Data collected in the early 1980s showed relatively rapid infiltration through the three bio-barrier test plots, which are largely constructed with cobbles, as compared to the crushed tuff test plot, which represents a traditional interim cover used at Area G (Nyhan et al., 1986; Nyhan et al., 1989). Numerical simulations presented in this SA indicate that between 1982 and 2016, approximately twice the infiltration may have occurred through the three test plots constructed with cobbles compared to the test plot constructed with crushed tuff and presumably compared to most of the rest of Pit 25, which has a crushed tuff interim cover. The cobble construction of three of the four test plots has high conductivity and little storage capacity to limit infiltration, and enhanced infiltration is almost certainly occurring. This condition is inconsistent with assumptions related to groundwater flow used in the PA/CA. However, although infiltration is enhanced through the test plots, a qualitative assessment that compares the Pit 25 results to Pit 38 results indicates that significant transport of radionuclides to groundwater has probably not occurred because of the limited area covered by the test plots at Pit 25 and because $99 \%$ of the pit 25 inventory is made up of the short-lived radionuclides Co-60, Cs-137, and H-3.

\subsection{Recommendations for Corrective Actions}

This special analysis (SA) 2016-002 concludes that the interim cover on Pit 25 is subject to erosion because of runoff from the north. Also, $8 \%$ of the pit surface area is covered with test plots that increase infiltration into the pit in comparison to a traditional crushed tuff cover. Although the analysis indicates these conditions may not be of immediate concern in terms of site performance, the conditions are less protective than those assumed in the PA/CA models. The three test plots that are constructed largely of cobbles do not act to buffer precipitation events; effectively this 
area is behaving as though it lacks an interim cover in terms of limiting infiltration into the pit. Therefore, actions to repair and enhance the interim cover on Pit 25 are recommended to remedy these conditions.

This special analysis (SA) 2016-002 recommends the following corrective actions for the Pit 25 Area.

- Survey the $\mathrm{x}, \mathrm{y}, \mathrm{z}$ coordinates of the metal panels discovered in the Pit 25 cover. At the same time, and where possible, survey apparent pit edges/corners with $\mathrm{x}, \mathrm{y}$, and $\mathrm{z}$ coordinates for pits $25 \& 26$. The deliverable for this effort should be raw data and maps/drawings showing survey points.

- After surveys are complete, install fill material over Pits 25 and 26 that extends from (and is incorporated with) the cover over Pit 39. This material needs to extend at least 3 feet beyond the edges of Pits 25 and 26, and should be gently sloped in a southerly direction to decrease further erosion. Install a minimum of $2 \mathrm{ft}$ of additional cover over the entire surface of Pit 25 to decrease infiltration. Top soil or appropriate amendments should be incorporated into this material to support re-vegetation, which will also help decrease infiltration and stabilize the cover with respect to erosion. The new cover material should be planted with native vegetation, and the use of erosion matting is also a good idea. ENV-CP can provide useful direction and information on appropriate seed mixes and matting. EP-AP-2202 provides useful direction and information for surveys and installation of additional cover material.

- After installation of additional cover material is complete, follow-on surveys should be performed to record the new cover coordinates and elevations. The same deliverables should be obtained for the final surveys including raw data and maps/drawings showing survey points. 


\subsection{References}

Chu, S., K. Birdsell, P. Stauffer, and R. Shuman, 2017, Special Analysis: 2016-003, Upgrade of Area G PA-CA Model to Updated Versions of GoldSim Software and to LANL Analysts, Los Alamos National Laboratory Report LA-UR-17-20616, February.

Dai, D., K. Birdsell, P. Stauffer, and B. Newman, 2018, Simulations of Moisture Movement through Pits 37 and 38 at Los Alamos National Laboratory Technical Area 54, Area G, Los Alamos National Laboratory Report LA-UR-18-23686, May.

French S.B., D. Levitt, P. Stauffer, K. Birdsell, and R. Shuman, 2013, Special Analysis 2012-007: Impacts of Water Introduced into Pits 37 and 38 at Technical Area 54, Area G, Los Alamos National Laboratory Report LA-UR-13-22839, March.

French, S.B. and R. Shuman, 2015, Radioactive Waste Inventory for Los Alamos National Laboratory Technical Area 54, Area G, Revision 2, Los Alamos National Laboratory Report LAUR-15-20428, January.

LANL, 2008, Performance Assessment and Composite Analysis for Los Alamos National Laboratory Technical Area 54, Material Disposal Area G - Revision 4, Los Alamos National Laboratory Report LA-UR-08-06764, October.

LANL, 2013, Conduct of Engineering, Calculation Document: Am-241 Under Reporting, CAL54-MULT-01247, Form No. AP-341-605-FM02, Rev. 3, Effective Date 7/24/13.

LANL, 2014, Review of Nitrate Wastes Associated with Plutonium Purification and Recovery Operations at Los Alamos National Laboratory, LA-UR-14-24715, June.

Pawar, R., S. Chu, A. Atchley, and P. Stauffer, 2018, Groundwater Modeling and Predictions of C-14 Transport from Pit 38 at Material Disposal Area G, Los Alamos National Laboratory Report LA-UR-18-23491, May.

Software QA for NucDataR02B, WDP-DO-09-0233, Los Alamos National Laboratory Memorandum, Dec 15, 2009 and the associated Excel Utility (NucDataR02C.xlsx).

Veilleux, J.M., 2005, Determination of Plutonium Mass Fractions and Uncertainties from Waste Assay Measurements, Los Alamos National Laboratory Report LA-UR-05-8922, November. 


\section{Appendix A}

\section{Unreviewed Disposal Question Evaluation, UDQE 1602}




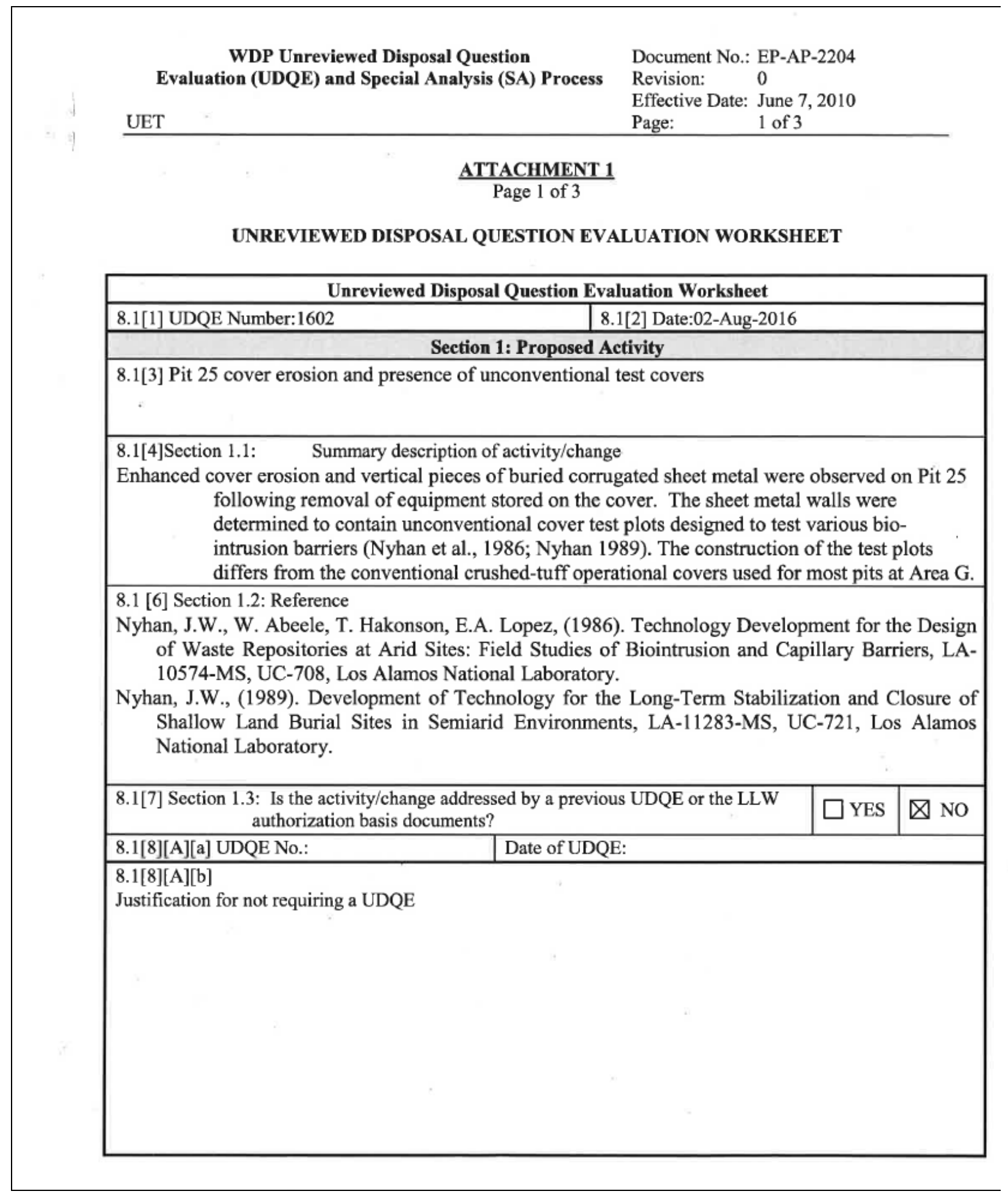




\section{WDP Unreviewed Disposal Question Evaluation (UDQE) and Special Analysis (SA) Process}

Document No.: EP-AP-2204

Revision:

0

Effective Date: June 7, 2010

Page:
2 of 3

ATTACHMENT 1

Page 2 of 3

UNREVIEWED DISPOSAL QUESTION EVALUATION WORKSHEET

\begin{tabular}{|c|c|c|c|}
\hline $8.1[1$ & 1] UDQE Number: 1602 & & \\
\hline $8.1[1$ & Section 2: UDQE- Screening & & \\
\hline 2.1 & Waste Characteristics & Not App & cable \\
\hline & $\begin{array}{l}\text { Does the requested variance to the Area G WAC involve a technical issue (including } \\
\text { radionuclide content, container specifications, amount of void space in containers, waste } \\
\text { form, etc.)? }\end{array}$ & $\square$ YES & $\square$ NO \\
\hline & $\begin{array}{l}\text { Does disposal of radioactive waste within Area } \mathrm{G} \text { which requires a variance to the LANL } \\
\text { WAC, P 930-1? }\end{array}$ & $\square$ YES & $\square$ NO \\
\hline c. & Does the proposed activity involve the retrieval of below ground waste? & $\square$ YES & $\square \mathrm{NO}$ \\
\hline & Disposal Practices & Not App & cable \\
\hline a. & Does the depth of waste placement exceed the depth of placement modeled in the PA/CA? & $\square$ YES & $\square \mathrm{NO}$ \\
\hline & $\begin{array}{l}\text { Will the distance between the top of the disposed waste and the ground surface be less than } \\
\text { the distance specified in the PA/CA? }\end{array}$ & $\square$ YES & $\square$ NO \\
\hline 2.3 & Procedures/Documents/Systems & Not Appl & able \\
\hline & $\begin{array}{l}\text { Does the procedure or process changes define, control or administer LLW characterization } \\
\text { and/or disposal activities? }\end{array}$ & $\square$ YES & $\square \mathrm{NO}$ \\
\hline b. & Does the activity invoke changes to DAS? & $\square$ YES & $\square \mathrm{NO}$ \\
\hline & $\begin{array}{l}\text { Does the activity change the Chem/LL database information that impacts LLW volume, } \\
\text { activity, and or mass information, or the methods for calculating database quantities? }\end{array}$ & $\square$ YES & $\square$ NO \\
\hline 2.4 & Site/Facility Construction & Not Ap & able \\
\hline & $\begin{array}{l}\text { Does the proposed activity involve the addition/modification of structures, affect water } \\
\text { runoff configurations, or impact the characterization/monitoring wells and/or equipment } \\
\text { which are currently located at Area G? }\end{array}$ & $\square$ YES & $\square$ No \\
\hline & $\begin{array}{l}\text { Does the proposed activity bring the facility/site back into compliance with current } \\
\text { assumptions regarding site configurations and operations as defined within PA/CA and } \\
\text { applicable Area G disposal authorization basis documents? }\end{array}$ & $\square$ YES & $\square$ NO \\
\hline c. & Does the proposed activity involve the drilling of new boreholes or monitoring wells? & $\square$ YES & $\square \mathrm{NO}$ \\
\hline & $\begin{array}{l}\text { Will the proposed activity require changes in site grading or storm waste runoff control } \\
\text { provisions? }\end{array}$ & $\square$ YES & $\square$ NO \\
\hline 2.5 & New Disposal Unit Construction & Not App. & cable \\
\hline & $\begin{array}{l}\text { Do any design parameters differ from the PA/CA and applicable Area } \mathrm{G} \text { disposal } \\
\text { authorization basis documents? These parameters include, but are not limited to, disposal } \\
\text { unit dimensions, distance of units from the mesa edge, and depth of disposal units. }\end{array}$ & $\square$ YES & $\square$ NO \\
\hline b. & Is there construction of new site structures or facilities? & $\square$ YES & $\square \mathrm{NO}$ \\
\hline c. & Is there contruction activities for removal of existing site structures or features? & $\square$ YES & $\square \mathrm{NO}$ \\
\hline d. & Is there construction activities for creation of new disposal units (pits and shafts)? & $\square$ YES & $\square \mathrm{NO}$ \\
\hline 2.6 & Interim/ Final Disposal Unit Closure & Not Appl & cable \\
\hline & $\begin{array}{l}\text { Will the minimum depth of cover between the top of the waste and the ground surface be } \\
\text { less than that specified in the PA/CA and applicable DAB documents? }\end{array}$ & $\triangle \mathrm{YES}$ & $\square$ NO \\
\hline & $\begin{array}{l}\text { Do any design parameters of the cover differ from the PA/CA and applicable Area } \mathrm{G} \\
\text { disposal authorization basis documents? These parameters include, but are not limited to, } \\
\text { slope, material properties, performance characteristics, and depth. }\end{array}$ & $\triangle \mathrm{YES}$ & $\square$ NO \\
\hline & $\begin{array}{l}\text { Does the proposed activity affect the closure of active disposal pits and shafts or } \\
\text { installation of operational or final covers? }\end{array}$ & QYES & $\square$ NO \\
\hline
\end{tabular}


WDP Unreviewed Disposal Question

Evaluation (UDQE) and Special Analysis (SA) Process
Document No.: EP-AP-2204

Revision:

Effective Date: June 7, 2010

Page: 3 of 3

ATTACHMENT 1

Page 3 of 3

8.1[1] UDQE Number: 1602

8.1[2] Date:02-Aug-2016

If the answers to all applicable questions in Section 2 are "No", the activity/change does constitute a UDQ; proceed to Section 3: UDQ Evaluation Summary and Approval.

Section 3: UDQ Evaluation Summary and Approval

UDQ Number: 1602

Date: 02-Aug-2016

8.1[11] $\square \quad$ This activity/change does not (all responses are "No") constitute a UDQ

$\bigotimes \quad$ This activity/change does (at least one response is "YES") constitute a UDQ and a Special Analysis is required prior to implementing the activity/change

Pit 25 has an operational cover. However, part of the cover is an unconventional design to test bio-barriers that was observed to enhance infiltration beneath the covers and into the underlying waste layer (Nyhan et al., 1986; Nyhan 1989). In addition, the cover shows significant signs of erosion. These conditions differ from those assumed in the Area G Performance Assessment and Composite Analysis.

\begin{tabular}{|c|c|c|}
\hline \multicolumn{3}{|l|}{ 8.1[12] UDQ Evaluator } \\
\hline \multicolumn{3}{|l|}{ Name (Print) Philip H. Stauffer } \\
\hline \multicolumn{3}{|l|}{ 8.1[13] UDQE Reviewer } \\
\hline \multicolumn{3}{|l|}{ Name (Print)Philip H. Stauffer } \\
\hline \multicolumn{3}{|c|}{ ADC: $\otimes$ Unclassified $\square$ ouo $\square$ UCNI $\square$ Classified } \\
\hline \multicolumn{3}{|l|}{ Derivative Classifier } \\
\hline Name (Print) Philip H. Stauffer & Signature: & Date: \\
\hline \multicolumn{3}{|c|}{ Section 4 FINAL APPROVAL } \\
\hline \multicolumn{3}{|c|}{ 8.1[19]/9.[7] N3B Waste and Engineering Manager } \\
\hline Name (Print) Ellen Gammon & Signature: $\mathrm{elch}$ & Date: $2 / 6 / 19$ \\
\hline
\end{tabular}




\section{Appendix B}

\section{Simulations of Moisture Movement through Four Bio-Intrusion Test Plots at Pit 25, Area G}




\section{B-1 Numerical Model Set Up for Infiltration through Pit 25 Test Plots}

A two-dimensional, cross-sectional model was built using the Hydrus2D flow model (Šimůnek et al., 2011) to simulate water percolation through the four bio-intrusion barriers into the waste and backfill at Pit 25. A photograph of the test plots is shown in Figure 2-3 of the main body of this report. Figure B-1 shows the conceptual domain for the model, and Figure B-2 shows the Hydrus2D numerical grid (Figure 3). The model vertically consists of $15 \mathrm{~cm}$ of topsoil, $1 \mathrm{~m}$ of bio-intrusion barrier, $11 \mathrm{~m}$ of waste and backfill, and $1 \mathrm{~m}$ of the Tshirege Member unit 2 of the Bandelier Tuff at the bottom. Mesh refinements were conducted for the topsoil and thin layers of gravel and cobble to capture the heterogeneous structure and the layer boundaries for the test plots (Figure B-2). The top of the model uses an atmosphere boundary to receive recharge from precipitation. Observed precipitation data from January 1, 1982 to January 18, 2016, from the TA-54 weather station, as well as the calculated daily evaporation and transpiration rates, are applied on the top boundary. The left and right sides are no-flow boundaries. The bottom is a constant head boundary (with a hydraulic pressure of $-8 \mathrm{~m}$, which represents a constant water content of $12 \%)$. The initial hydraulic pressures for different material zones are assigned based on the monitoring data on January 1, 1982.

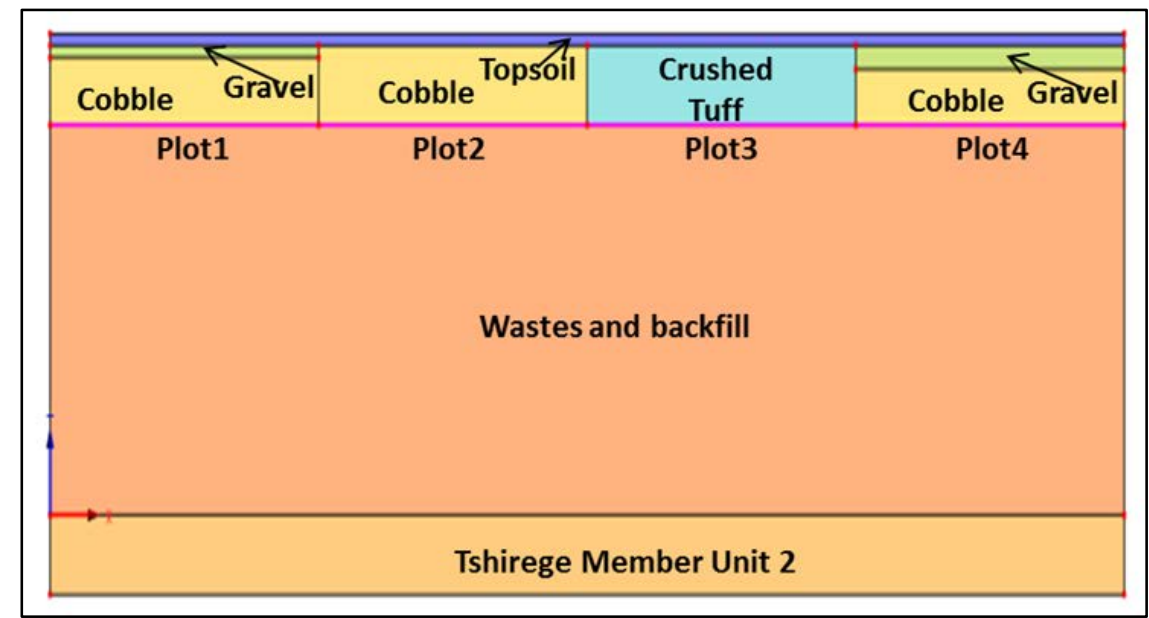

Figure B-1: A two-dimensional framework model for Pit 25 with topsoil, four different biointrusion-barriers, waste and backfill, and Tshirege Member Unit 2. 


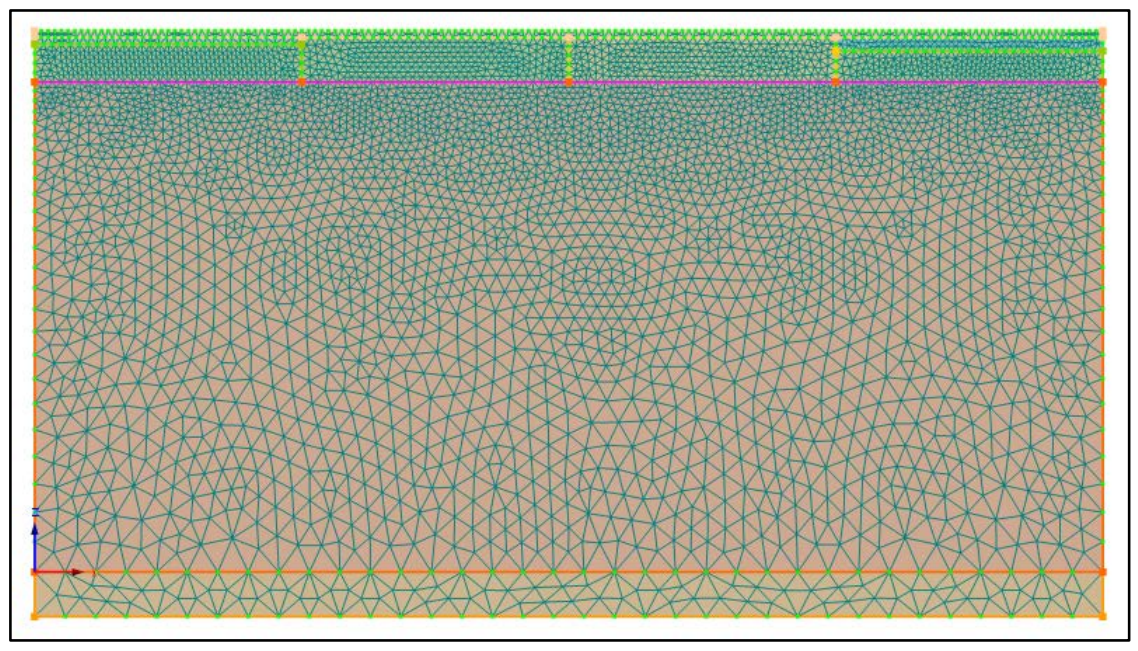

Figure B-2: Numerical grid of the two-dimensional Hydrus model for Pit 25

\section{B-2 Model calibration and parameter estimation}

To calibrate the two-dimensional, numerical model and estimate the model parameters, we used two sets of time-series and spatial-series data for inverse modeling (Nyhan et al. 1986; Nyhan et al. 1989). Neutron moisture access tubes were installed to a depth of $137 \mathrm{~cm}$ (or $30 \mathrm{~cm}$ into the backfill) through each of the four plots and into the underlying backfill to allow for time-series monitoring of moisture in the backfill. The monitoring started in January 1, 1982 and ended in August 13, 1985. In addition, soil water content was monitored in each of the four plots, at different depths (spatial-series) from $10 \mathrm{~cm}$ to $137 \mathrm{~cm}$ for a single event at the end of April, 1985.

Parameter estimation was conducted using a trial-and-error method. The initial hydrologic parameters for the crushed tuff and backfill (waste) were obtained from previous studies (Levitt, 2008, 2011), while those of gravel and cobble are mainly from literature (Sanford et al., 1996; Ferdos et al., 2015). We manually adjusted the saturated hydraulic conductivities, porosities, and van Genuchten (1980; 1987) parameters for the different cover materials and then ran the numerical model more than 50 times to match the monitored and computed water contents for the time-series and spatial-series data. Finally, some reasonable fits between the simulation results and the field data were obtained and are shown in Figures B-3, B-4, and B-4. The main time-variations and trends in water contents beneath the four plots (at depths of $137 \mathrm{~cm}$ ) are fit reasonably well (see Figure B-4). The vertical-spatial-variations in the four plots are also well fit (see Figure B-5). The final estimated parameters are listed in Table B-1. 
Table B-1: Estimated parameters for the bio-intrusion barrier and backfill

\begin{tabular}{|c|c|c|c|c|c|c|}
\hline \multirow[b]{2}{*}{ Materials and units } & \multicolumn{2}{|c|}{$\begin{array}{c}\text { Volumetric Water } \\
\text { Content }\end{array}$} & \multicolumn{2}{|c|}{$\begin{array}{c}\text { van Genuchten } \\
\text { Parameters } \\
\end{array}$} & \multirow{2}{*}{$\begin{array}{l}\text { Saturated } \\
\text { Conductivity } \\
\text { (m/day) }\end{array}$} & \multirow{2}{*}{$\begin{array}{c}\text { Sources for initial } \\
\text { values }\end{array}$} \\
\hline & Residual & Saturated & $\alpha(1 / \mathbf{m})$ & $\mathbf{n}$ & & \\
\hline Topsoil & $0.025^{\mathrm{a}}$ & 0.41 & 1.3 & 1.2 & 0.81 & Stauffer et al. (2005) \\
\hline Gravel & 0.02 & 0.35 & 1.5 & 2.0 & 30.0 & Sanford et al. (1996) \\
\hline Cobble & 0.01 & 0.38 & 1.5 & 2.4 & 340.0 & Ferdos et al. (2015) \\
\hline Crushed Tuff & 0.02 & 0.39 & 1.3 & 1.8 & 0.55 & Levitt (2008) \\
\hline Waste \& backfill & 0.02 & 0.3 & 1.43 & 1.5 & 0.25 & Levitt (2008) \\
\hline Tshirege Member Unit 2 & 0.024 & 0.41 & 0.47 & 2.1 & $0.17^{\mathrm{b}}$ & Stauffer et al. (2005) \\
\hline
\end{tabular}

${ }^{a}$ Increased from value of 0.0 in Table III-1, Stauffer et al. (2005) to reflect more realistic value

${ }^{b}$ Calculated from permeability value;

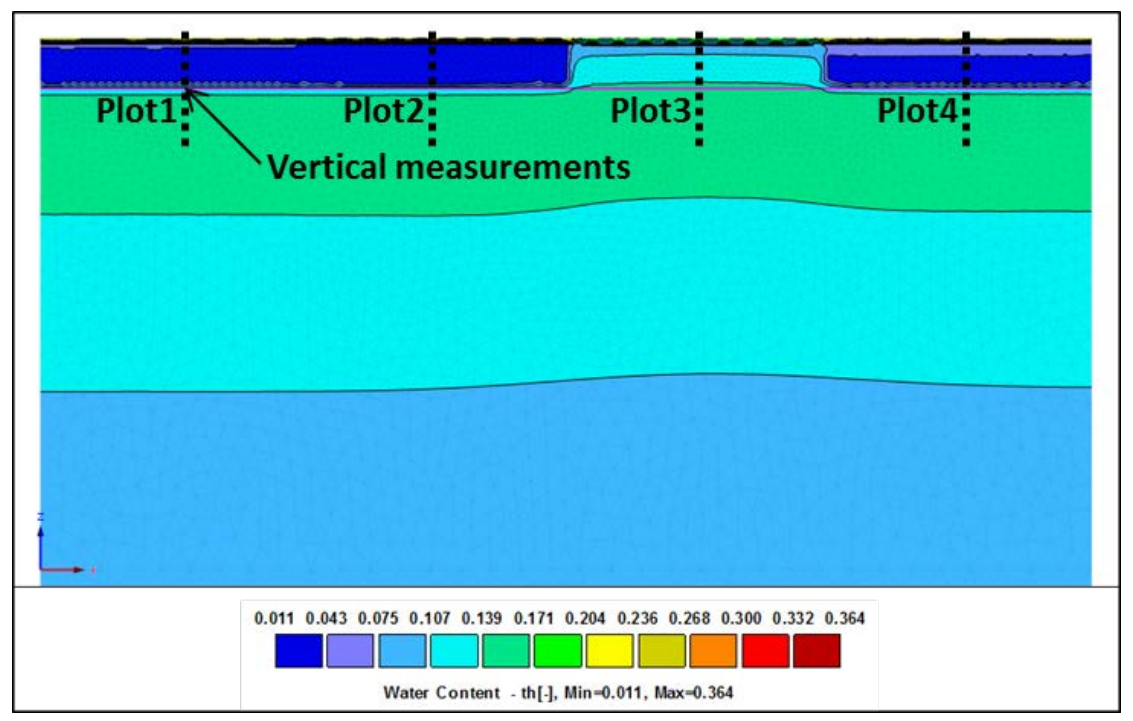

Figure B-3: Simulated water contents at the end of April, 1985 for Pit 25 with the four bio-intrusion barriers 


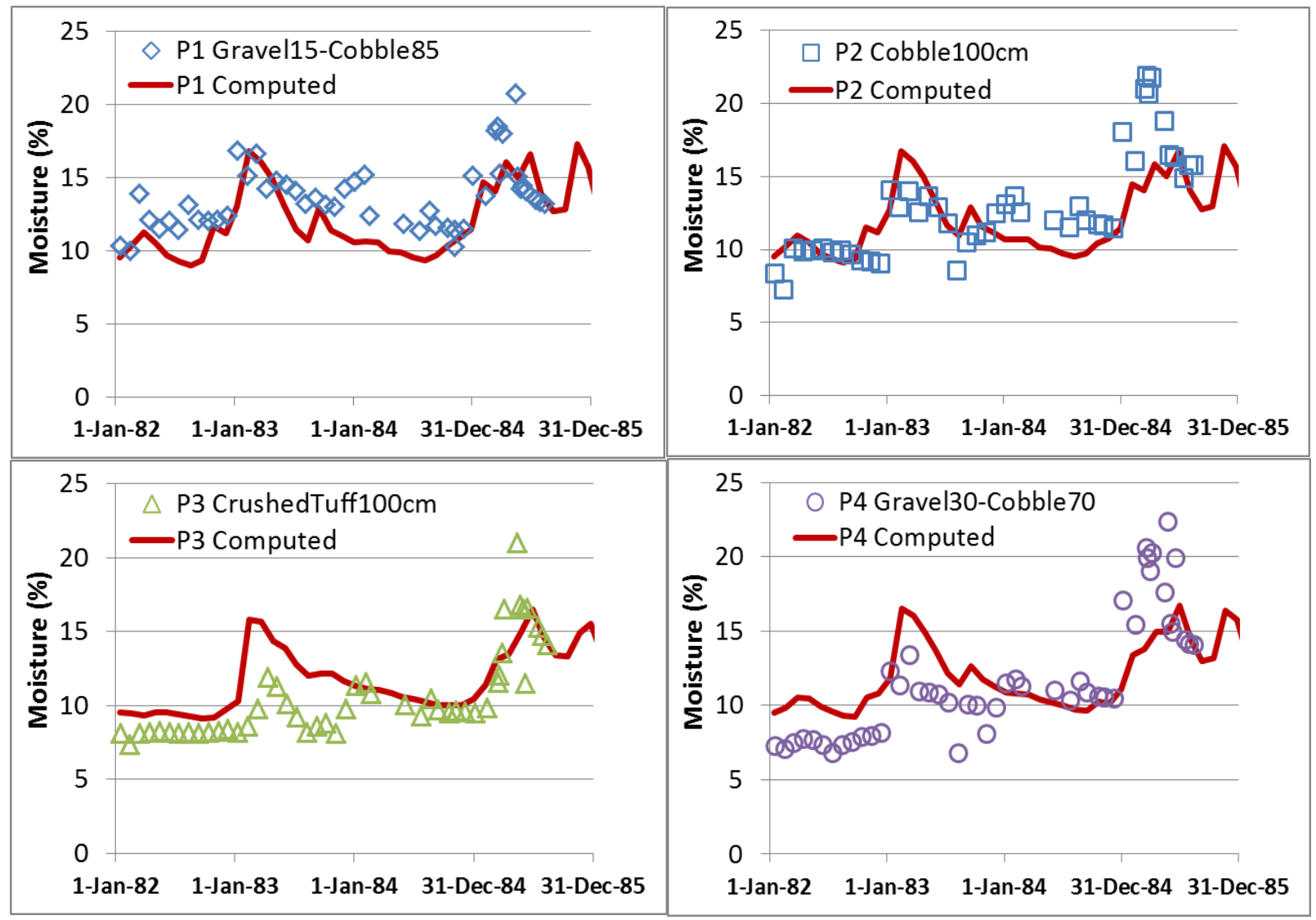

Figure B-4: Comparison of the measured and computed water contents beneath the four plots at a depth of $137 \mathrm{~cm}$ (note: $P=$ Plot) 

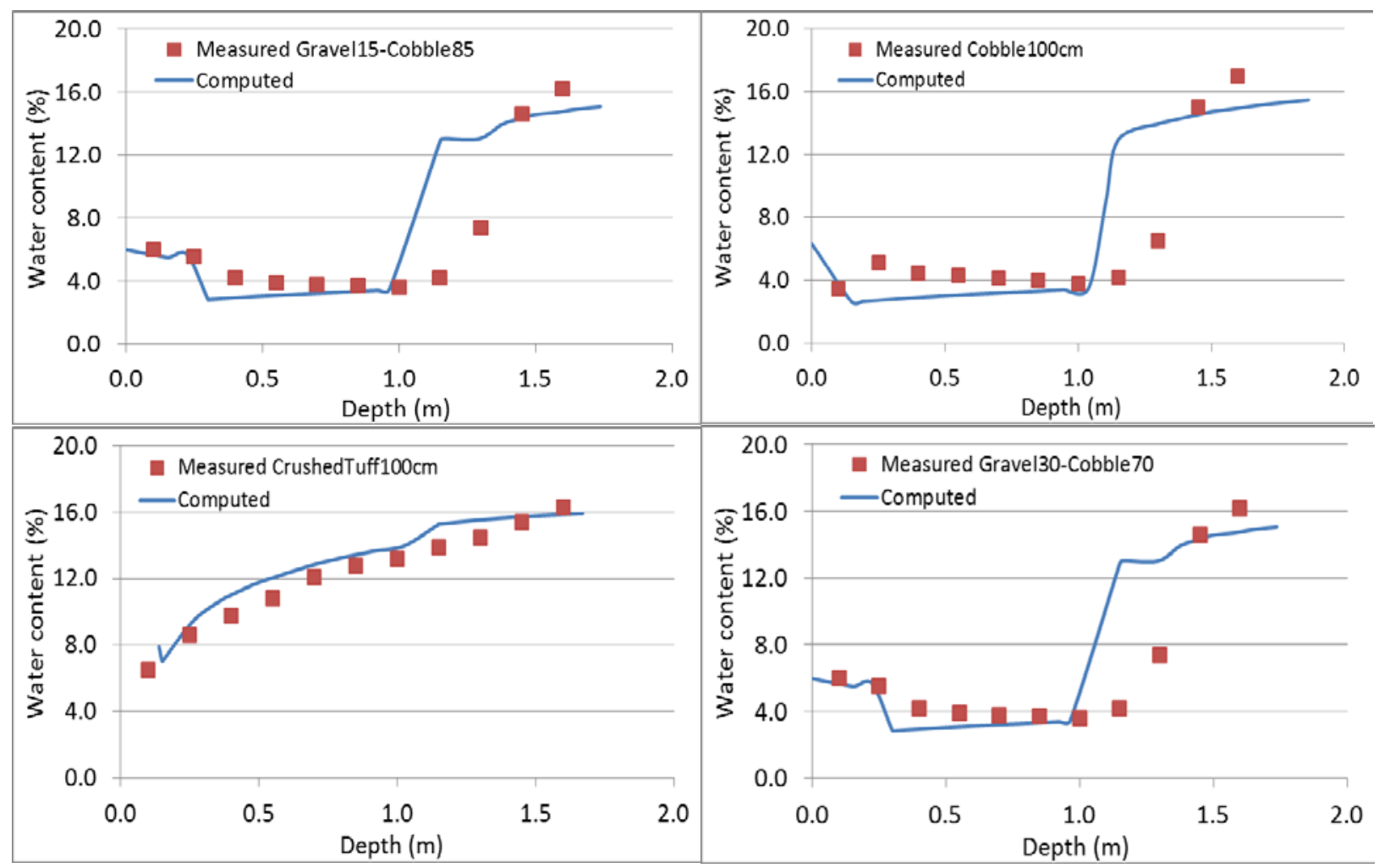

\section{Figure B-5: Comparison of the measured and computed water contents (\%) along a vertical line within the four plots at different depths}

\section{B-3 Water percolation from the bio-intrusion barrier}

Water percolation rates across the bottom of the four test plots were calculated for the time period from January 1, 1982 to January 18, 2016 By running the numerical model using the estimated parameters and observed precipitation data. The computed time-series flow rates are presented in Figure B-6. The important features of the computed percolation rates are that flow rates beneath Plot 2 (100 cm of cobble) are the largest because the cobble has the largest conductivity and the van Genuchten parameters are not condusive to retaining water. The percolation rates through Plot 1 (15 cm gravel and $85 \mathrm{~cm}$ cobble) and Plot 4 (30 gravel and 70 cobble) have the same behavior; flow rates beneath Plot 1 are larger than those for Plot 4 because of the higher ratio of cobble to gravel. The impacts of the large rainfall event in September 2013 on the flow rates are clear for Plots 1, 2 and 4, but not clearly shown for Plot 3. The flow rate across the bottom of Plot 3 (100 cm crushed tuff) is the smallest because crushed tuff has the smallest conductivity and the highest water retention capacity (i.e., ability to damp out transient pulses). Plot 3 is constructed similarly to the conventional operational cover at Area G.

The cumulative flow rate across the bottom of the crushed tuff plot is much less than those of the other three test plots (Figure B-7), which have less water retention capacity because of the large percentage of cobble (70-100\%) present in the cover. These results indicate that over twice (2.3 
time) the volume of water has percolated into the waste through Plot 2, which is constructed of cobbles, than through Plot 3, which is constructed of crushed tuff. Cummulative flows through Plot 1 (2.0 times) and Plot 4 (1.7 times) are also significantly higher than through Plot 3. Therefore, enhanced infiltration occurs through the test plots in comparison to a conventional operational cover constructed of crused tuff.

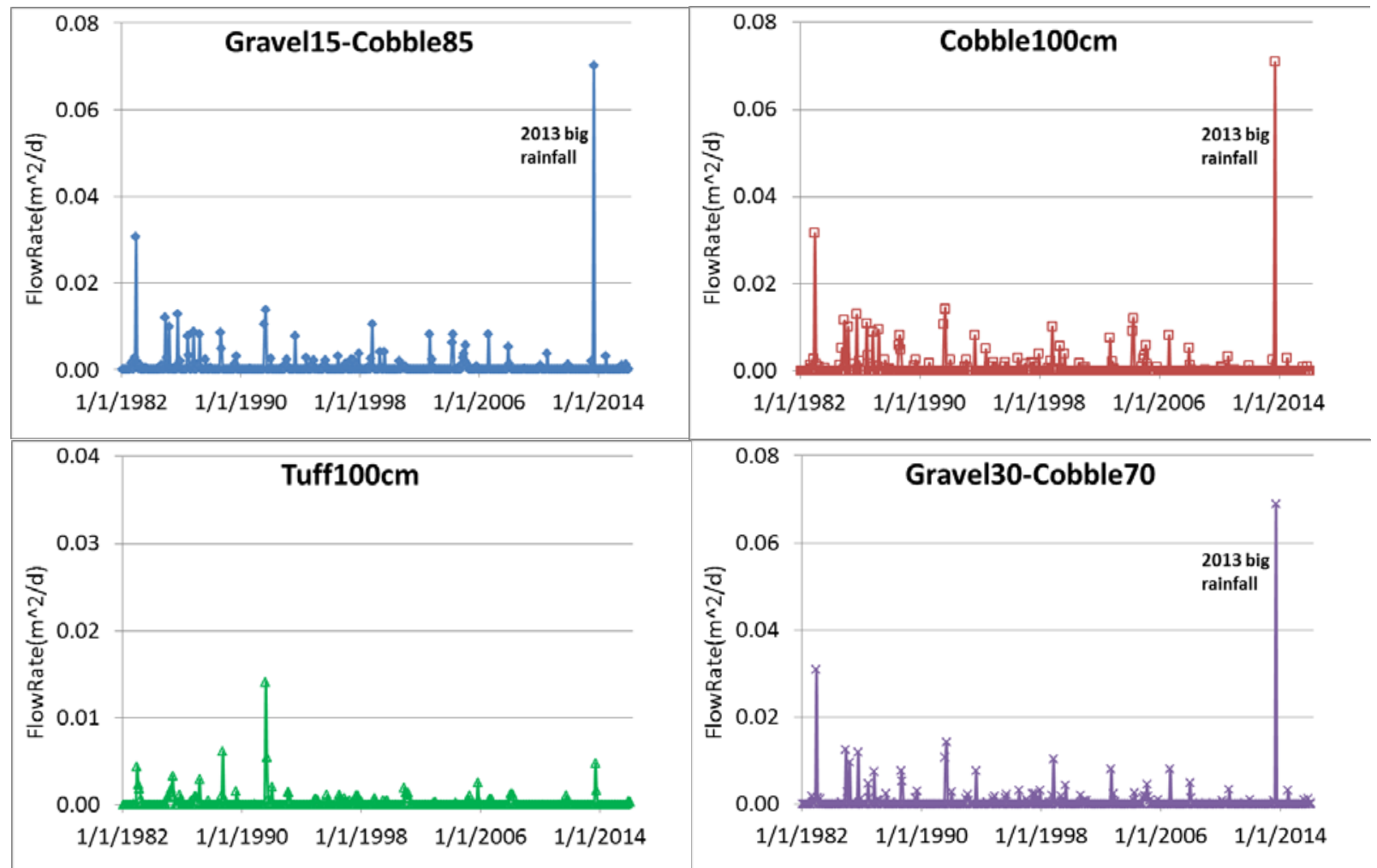

Figure B-6: Computed water flow rates $\left(\mathrm{m}^{2} / \mathrm{d}\right)$ across the bottoms of the four plots

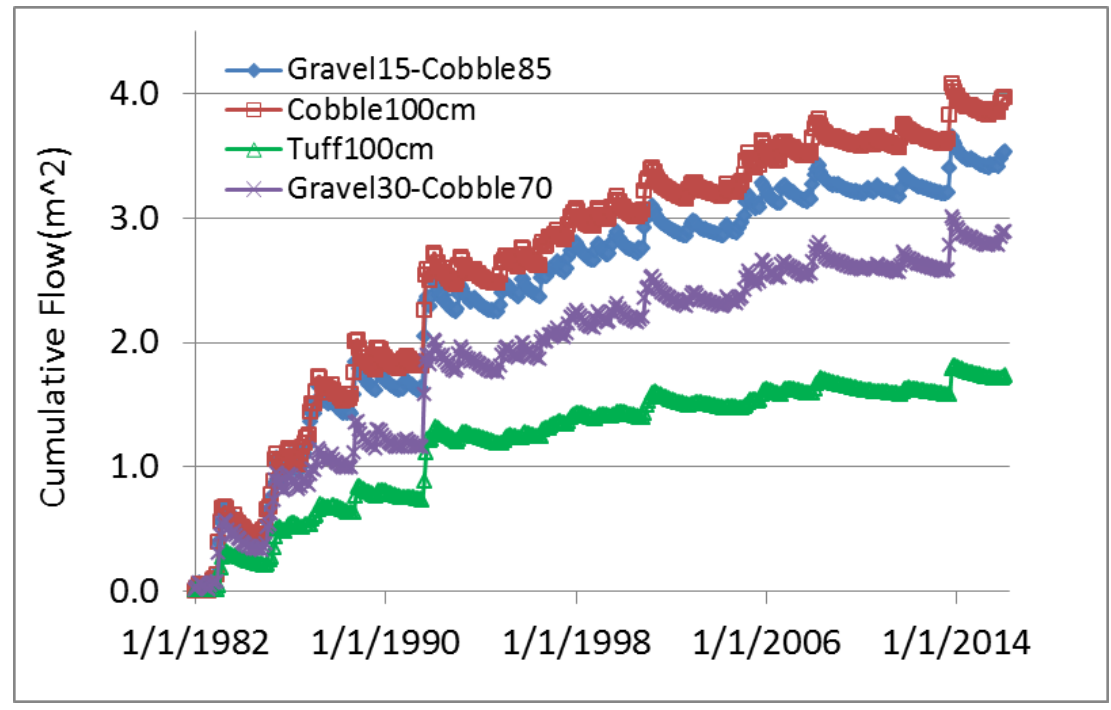

Figure B-7: Computed cumulative water flow rates $\left(\mathrm{m}^{2}\right)$ across the bottoms of the four plots 


\section{B-4 References}

Ferdos, F., A. Wörman, I. Ekström, Hydraulic Conductivity of Coarse Rockfill used in Hydraulic Structures, Transport in Porous Media, 108(2), pp 367-391, 2015.

Levitt, D.G., (2008). Modeling of an Evapotranspiration Cover for the Groundwater Pathway at Los Alamos National Laboratory Technical Area 54, Area G, Los Alamos National Laboratory Report LA-UR-08-5468, Los Alamos, New Mexico. August.

Levitt, D.G., (2011). Modeling the Movement of Transient Moisture through Disposal Units at Los Alamos National Laboratory Technical Area 54, Area G, Los Alamos National Laboratory Report LA-UR-11-05424, Los Alamos, New Mexico.

Nyhan, J.W., W. Abeele, T. Hakonson, E.A. Lopez, (1986). Technology Development for the Design of Waste Repositories at Arid Sites: Field Studies of Biointrusion and Capillary Barriers, LA-10574-MS, UC-708, Los Alamos National Laboratory.

Nyhan, J.W., (1989). Development of Technology for the Long-Term Stabilization and Closure of Shallow Land Burial Sites in Semiarid Environments, LA-11283-MS, UC-721, Los Alamos National Laboratory.

Sanford, W., T. S. Steenhuis, J.-Y. Parlange, J. M. Surface, J. H. Peverly, Hydraulic conductivity of gravel and sand as substrates in rock-reed filters, Ecological Engineering, 4(4), 321-336, 1995.

Šimůnek J, van Genuchten M Th and Šejna M (2011) The HYDRUS Software Package for Simulating Two- and Three-Dimensional Movement of Water, Heat, and Multiple Solutes in Variably-Saturated Media, Technical Manual, Version 2.0, PC Progress, Prague, Czech Republic, pp. 258.

Stauffer, P.H., H.S. Viswanathan, B.A. Robinson, C.W. Gable, G.L. Cole, D.E. Broxton, E.P. Springer, and T.G. Schofield, (2005). Groundwater Pathway Model for the Los Alamos National Laboratory Technical Area 54, Material Disposal Area G, Los Alamos National Laboratory Report LA-UR-05-7393, September.

van Genuchten M. Th (1980) A closed-form equation for predicting the hydraulic conductivity of unsaturated soils, Soil Sci. Soc. Am. J., 44, 892-898.

van Genuchten M Th (1987) A numerical model for water and solute movement in and below the root zone. Research Report No 121, U.S. Salinity laboratory, USDA, ARS, Riverside, California. 